\title{
Permissible Accommodations of Religion: Reconsidering the New York Get Statute
}

\author{
Tanina Rostain
}

\section{INTRODUCTION}

For a married couple to be divorced under Conservative or Orthodox Jewish law, the husband must prepare and present to his wife a bill of divorce or get $t^{2}$ under the supervision of a rabbi. ${ }^{2}$ The wife may not procure a divorce on her own. ${ }^{3}$ If the husband leaves his wife without presenting a get to her, neither party may remarry under Jewish law. ${ }^{4}$ The wife must bear additional disabilities: ${ }^{6}$ Her involvement in Jewish

1. I. Haut, Divorce in Jewish Law and Life 17 (1983); I. KLein, A Guide to Jewish ReLigrous PRACrice 467 (1979). The requirement originates in Deuteronomy 24:1 (Soncino):

When a man taketh a wife, and marrieth her, then it cometh to pass, if she find no favour in his eyes, because he hath found some unseemly thing in her, that he writeth her a bill of divorcement, and giveth it in her hand, and sendeth her out of his house . . . .

A get is not required in the Reform tradition. See M. LAMm, THE JEwish Way IN Love and MARRIAGE 48 (1980). Accordingly, this Note addresses the issue of Jewish divorce only as it arises in the Conservative and Orthodox traditions. Hereinafter, "Jewish law" and "Judaism" are used to refer to these traditions.

2. See I. HAUT, supra note 1, at 31 (divorce proceeding must be conducted in presence of most learned authorities). The procedural formalities that attend the preparation and delivery of a get are routine but complex; therefore they require expert rabbinical supervision. See id. The rabbi, however, does not grant the divorce; the husband's presentation and the wife's receipt of the get suffice, under normal circumstances, to effect the divorce. I. KLEIN, supra note 1 , at 467 . For a summary of the historical development of the formalities attending the presentation of a get, see generally D. AMRAM, The Jewish Law of Divorce According to Bible and Talmud 132-204 (1896).

3. I. HAUT, supra note 1 , at 18.

4. I. KLEIN, supra note 1, at 383 . In biblical times Judaism permitted polygamous marriage for men. Today, Jewish law prohibits polygamy except in a few, limited circumstances. Id. at 388-90.

5. She is relegated to the status of an agunah. "The agunah is a woman whose marriage is in fact ended or suspended, but who legally remains a married woman . . . unable to remarry." $R$. BIALE, WOMEN AND JEWISH LAW 102 (1984). The circumstances in which a wife becomes an agunah include abandonment by her husband and the death of her husband when there is no valid testimony regarding his death, id.; the marital status of a woman whose husband has abandoned her remains in limbo until he grants her a get. I. KLEIN, supra note 1, at 450-51. Judaism considers the fate of the agunah to be tragic. R. BIALE, supra, at 102. In fact, Jewish law has relaxed its traditional testimonial requirements so that a woman may more easily prove the death of her husband and remarry. Id. at 104-05. For a powerful depiction of the fate of the agunah, see C. GRADE, THE AGUNAH (1974).

Any subsequent relations with another man, including relations within a civil marriage, render the agunah an adulteress under Jewish law. G. HorowITz, THE SPIRIT OF JewISH LAw 204 (1953). In biblical times, a wife's adultery was punishable by death. Later, the penalty was flogging and automatic divorce. Id. at 205. No comparable sanctions were imposed on a man engaging in extramarital affairs. Id. at $204 \&$ n.21. While such sanctions are not enforced currently, an adulteress suffers the outcast status that Jewish law imposes on any child she bears from the tainted union. See infra note 7 and accompanying text. 
religious life becomes circumscribed. ${ }^{6}$ Moreover, any children she bears from a subsequent sexual union are excluded by Jewish law from participation in the Jewish community. ${ }^{7}$ Her husband does not suffer such severe consequences. ${ }^{8}$

With the availability of civil divorce, many husbands married under Jewish law have sought and obtained civil divorces without giving their wives a get. $^{{ }^{\circ}}$ For the most part, they have been motivated by spite or by the desire to obtain a favorable alimony settlement. ${ }^{10}$ Their wives have been unable to remarry under Jewish lavr or have been forced to bargain away a part of their rightful alimony to obtain a get.

In response to this problem, the New York Legislature enacted Domestic Relations Law section 253, ${ }^{11}$ commonly referred to as the get statute. The law requires that a party filing for divorce remove all conscientious or religious barriers within his or her power to the remarriage of the other spouse. ${ }^{12}$ The statute raises anew the question of how far government is permitted under the establishment clause ${ }^{13}$ to facilitate religious practices central to the identity and continued existence of a religious community. ${ }^{14}$

6. An observant Jewish woman fulfills important religious obligations within marriage. See infra note 117 and accompanying text.

7. See G. HoRowITZ, supra note 5, at 264. Children born of an adulterous woman are mamzerim and are not permitted to enter the " "congregation of the Lord" "; that is, they are not permitted to marry Jews who are not mamzerim. Id. (quoting Deuteronomy 23:3).

8. Judaism does not condone a man's extramarital affairs or subsequent civil remarriage. Extramarital relations are forbidden in the Bible. Deuteronomy 23:18; see 2 M. Maimonides, SEFERHaMrrzvoty 322-23 (C. Chavel trans. 1967) (Negative Commandment 355). A subsequent civil remarriage might be treated as an extramarital affair or prohibited under the ban against polygamy that has been in force since the eleventh century. See I. KLEIN, supra note 1, at 388-89. Nevertheless, Jewish law imposes no disabilities on children begotten in such relationships. Children who are the product of a man's extramarital affair with a single woman are not mamzerim. See G. Horowrrz, supra note 5 , at 264 .

9. Bleich, Jewish Divorce: Judicial Misconceptions and Possible Means of Civil Enforcement, 16 ConN. L. REv. 201, 201 (1984).

10. Id. at 202.

11. N.Y. DoM. REL. LAW $\S 253$ (McKinney 1986). No legislative history of the statute is available. For a discussion of the background and purpose of the law, see id. $\S 253$ practice commentary at 851-53. At the time the statute was passed, an estimated 15,000 observant Orthodox and Conservative Jewish women were civilly divorced but had not received gets. Hentoff, Who Will Rescue the Jewish Women Chained in Limbo?, Village Voice, Sept. 13, 1983, at 6.

Before the get statute's enactment, the New York Court of Appeals had responded to the problem by enforcing a Jewish marriage agreement, or ketubah, which compelled the parties to appear before a rabbinic tribunal if marital difficulties arose. See Avizzur v. Avitzur, 58 N.Y.2d 108, 446 N.E.2d 136, 459 N.Y.S.2d 572, cert. denied, 464 U.S. 817 (1983). For further discussion of Avitzur, see infra note 132. An alternative solution to the get problem, based on liability for intentional infliction of emotional harm, has been suggested. See Note, Jewish Divorce: What Can Be Done in Secular Courts To Aid the Jewish Woman?, 19 GA. L. REv. 339 (1985).

12. N.Y. Dom. REL. LAw $\S 253(2)-(6)$. See infra note 123 for the relevant text of the statute.

13. U.S. ConST. amend. I.

14. The Supreme Court has confronted the issue regularly in the cases involving aid to parochial schools. See, e.g., Grand Rapids School Dist. v. Ball, 105 S. Gt. 3216 (1985); Lemon v. Kurtzman, 403 U.S. 602 (1971). 
While no court has yet ruled on the question, ${ }^{15}$ several commentators have expressed grave reservations about the constitutionality of the get statute. ${ }^{16}$ They argue that the statute violates the establishment clause by casting government into questions properly within the purview of religion, giving religious functionaries control over civil affairs, and using civil courts to advance religion. In contrast, one commentator suggests that such a statute's accommodation of a Jewish woman's right to remarry within Judaism might be sufficient to justify it as a permissible accommodation of religion under the establishment clause. ${ }^{17}$

Divergent analyses of the get statute's constitutionality under the establishment clause are not surprising, given the absence of a generally accepted approach that unifies free exercise and establishment jurisprudence. In their present states, neither establishment nor free exercise doctrine alone provides a basis to decide the constitutionality of the get statute, which raises both establishment and free exercise concerns. The Supreme Court has recognized a zone of accommodations of religion that are permitted by the establishment clause, though not required by the free exercise clause, ${ }^{18}$ but it has failed to articulate the relationship between the two clauses and thus to demarcate clearly this zone. ${ }^{19}$

15. The only decision addressing the constitutionality of the get statute is Chambers v. Chambers, 122 Misc. 2d 671, 471 N.Y.S.2d 958 (Sup. Ct. 1983). Chambers struck down $\$ 253(4)$, which required affidavits by both parties in uncontested proceedings, as an unconstitutional impairment of contracts.

16. See, e.g., Warmflash, The New York Approach to Enforcing Religious Marriage Contracts: From Avitzur to the Get Statute, 50 BROoKLyN L. REv. 229, 252 (1984) (get statute impermissibly advances religion); Note, Avitzur v. Avitzur and New York Domestic Relations Law Section 253: Civil Response to a Religious Dilemma, 49 AlB. L. Rev. 131, 167-68 (1984) (same); Note, Jewish Divorce and Secular Courts: The Promise of Avitzur, 73 Geo. L.J. 193, 206-07 (1984) (same); Comment, The Religion Clauses and Compelled Religious Divorces: A Study in Marital and Constitutional Separations, 80 Nw. U.L. REv. 204, 212-56 (1985) (get statute violates free exercise and establishment clauses); Kochen, Constitutional Implications of New York's "Get" Statute, N.Y.L.J., Oct. 27, 1983, at 1, col. 3 (get statute violates establishment clause because it lacks secular purpose, impermissibly advances religion, and entangles government in religious affairs).

17. Bleich, supra note 9, at 277-86. Professor Bleich discusses a precursor of $\S 253$, amendment A. 7980, enacted during the 1981-1982 legislative session but subsequently withdrawn from the governor's desk by its sponsor. Id. at 285. According to Professor Bleich, this amendment sought to codify divorce courts' traditional equity power to withhold divorces in situations in which granting a divorce would lead to an inequitable result, such as a party's inability to remarry within his or her religion. Id. at 286 . Professor Bleich avoids taking a position on $\S 253$, which, he suggests, may present more serious constitutional problems. Id. at 286-87 n.265.

18. Zorach v. Clauson, 343 U.S. 306 (1952) (upholding against establishment challenge program that released children from school premises for religious education and devotional exercises).

19. Although the Court in Zorach recognized that the contested time-release program implicated free exercise concerns, it failed to address the tension between the free exercise and establishment clauses. See id. at 313-14. In Walz v. Tax Comm'n, 397 U.S. 664 (1970), the Court stated, "[t]he limits of permissible state accommodation to religion are by no means co-extensive with the noninterference mandated by the Free Exercise Clause." Id. at 673. It noted that exempting churches from property taxes relieved burdens on religious exercise, but failed to explain how this observation informed its determination of nonestablishment. See id. Most recently, in Wallace v. Jaffree, 472 U.S. 38 (1985), Justice O'Connor pointed out the inadequacies of traditional establishment analysis in situations where legislation furthers free exercise by removing government-imposed burdens on reli- 
This Note proposes an approach to determining the permissibility of governmental accommodations of religion based on the norms embodied in both religion clauses. It defines an accommodation of religion as legislation that functions to remove governmentally imposed burdens on religious exercise. The Note next argues that establishment challenges to accommodations of religion should be evaluated under a different standard from that applied to legislation that does not meet the definition of accommodation. It then formulates a standard for the permissibility of a government accommodation of religion under the establishment clause that incorporates the legislation's status as an accommodation. Finally, the Note ap-

gious exercise. See id. at 82-83 (O'Connor, J., concurring in the judgment).

Numerous commentators have sought to reconcile the nonestablishment mandate and the free exercise guarantee. See, e.g., Choper, The Religion Clauses of the First Amendment: Reconciling the Conflict, 41 U. PrTr. L. REv. 673, 675 (1980) (establishment clause forbids "only government action whose purpose is solely religious and that is likely to impair religious freedom by coercing, compromising, or influencing religious beliefs") (emphasis omitted); Kurland, Of Church and State and the Supreme Court, 29 U. CHI. L. REv. 1, 96 (1961) (religion clauses prohibit "classification in terms of religion either to confer a benefit or to impose a burden" on religious exercise); Moore, The Supreme Court and the Relationship Between the "Establishment" and "Free Exercise" Clauses, 42 TEx. L. REv. 142, 196-97 (1963) (laws either having sufficient secular purpose or protecting free exercise do not violate establishment clause); Schwarz, No Imposition of Religion: The Establishment Clause Value, 77 YALE L.J. 692, 693 (1968) (accommodations of religion do not violate establishment clause unless their purpose or effect is imposition of religious belief or practice).

For a recent attempt to argue that accommodations of religious exercise are permissible under the establishment clause, see McConnell, Accommodation of Religion, 1985 SUP. CT. REv. 1. Professor McConnell does not distinguish between governmentally imposed and privately imposed burdens on religious exercise. Id. at 31-32. Consequently, his claim that government should be permitted to remove both types of burdens goes much further than this Note's argument that government may remove governmentally imposed burdens on religious exercise. See infra text accompanying notes 32-67. McConnell argues that permissible accommodations should encompass removal of private burdens on religious exercise by analogy to other areas, such as equal protection, in which government has compelled private individuals to conform to constitutional norms. McConnell, supra, at 32. McConnell overlooks the core nonestablishment principle that government may not require private individuals to bear the costs of facilitating the religious exercise of others. This principle is captured in Madison's famous rhetorical question in his Memorial and Remonstrance Against Religious Assessments: "[Who does not see t]hat the same authority which can force a citizen to contribute three pence only of his property for the support of any one establishment, may force him to conform to any other establishment in all cases whatsoever?" $2 \mathrm{~J}$. MADISON, WRITINGS 183, 186 (G. Hunt ed. 1901), reprinted in Everson v. Board of Educ., 330 U.S. 1, 65-66 app. (1946) (Rutledge, J., dissenting); see also infra notes 98-104 (government may not subsidize religious activities).

Where the free exercise clause requires government to accommodate religious exercise, the free exercise mandate has, sub silentio, overridden establishment concerns. In such cases the Court has done no more than gesture towards the establishment clause. See, e.g., Wisconsin v. Yoder 406 U.S. 205, 220-21 (1972) (establishment clause concerns do not justify withholding exemption required by free exercise clause); see also McDaniel v. Paty, 435 U.S. 618, 627-29 (1978) (Tennessee disqualification of cleric from service as delegate in election based on nonestablishment rationale violates cleric's free exercise of religion); L. TRIBE, American Constitutional LAw § 14-7, at 833-34 (1978) (free exercise principle dominant in cases of conflict). While the Court's nod toward the establishment clause may suffice in cases involving an exemption, such as Yoder, or nondiscrimination, such as McDaniel, it is inadequate in cases in which government takes affirmative steps to accommodate free exercise, as in the case of the military chaplaincy. See, e.g., Note, Military Mirrors on the Wall: Nonestablishment and the Military Chaplaincy, 95 Y ALE L.J. 1210, 1227-32 (1986) (military chaplaincy violates the establishment clause by excessively entangling government in religion and favoring ecumenical Protestantism over other religions). 
plies this standard to the get statute and concludes that it is a permissible accommodation of religion.

\section{Government ACCOMmodations of Religion}

\section{A. The Tension Between the Free Exercise Guarantee and the Nonestablishment Mandate}

The First Amendment states: "Congress shall make no law respecting an establishment of religion, or prohibiting the free exercise thereof . . ." "20 Together, the religion clauses create a division between a private sphere, within which the free exercise clause protects individual exercise of religion, and a public governmental sphere, from which the establishment clause excludes religion. ${ }^{21}$ The religion clauses envision a secular government under which a plurality of religious ways of life are free to flourish. ${ }^{22}$ In Zorach v. Clauson, Justice Douglas, writing for the Court, emphasized: "We sponsor an attitude on the part of government that shows no partiality to any one group and that lets each flourish according to the zeal of its adherents and appeal of its dogma."23

Despite the unified purpose underlying the religion clauses, either clause, "if expanded to a logical extreme, would tend to clash with the other."24 Through excessive solicitude for religious exercise, government may run afoul of the establishment clause. ${ }^{25}$ Conversely, too stringent application of the nonestablishment mandate may violate the free exercise guarantee. ${ }^{26}$ The expansion of the welfare state since World War II and the consequent blurring of the line between the governmental and private spheres have caused this conceptual tension, which is inherent in the religion clauses, to emerge acutely. ${ }^{27}$

20. U.S. ConST. amend. I. The free exercise and establishment clauses apply to the states through the Fourteenth Amendment. Cantwell v. Connecticut, 310 U.S. 296, 303 (1940).

21. "The Constitution decrees that religion must be a private matter for the individual, the family and the institutions of private choice . . . " Lemon v. Kurtzman, 403 U.S. 602, 625 (1971); see L. TRIBE, supra note $19, \S 14-3$, at 818 (identifying voluntarism and separatism as principles underlying Court's interpretation of religion clauses).

22. See, e.g., Zorach v. Clauson, 343 U.S. 306, 313-14 (1952).

23. Id. at 313.

24. Walz v. Tax Comm'n, 397 U.S. 664, 668-69 (1970).

25. See, e.g., Wallace v. Jaffree, 472 U.S. 38 (1985) (invalidating moment of silence statute).

26. See, e.g., McDaniel v. Paty, 435 U.S. 618 (1978) (free exercise clause prohibits Tennessee from barring cleric from serving as state constitutional delegate notwithstanding state's nonestablishment rationale).

27. See Note, Civil Religion and the Establishment Clause, 95 YaLE L.J. 1237, 1243 \& n.33 (1986) ("seemingly crisp dichotomies" of Lemon test inadequate to deal with complexities of churchstate relations since New Deal). Many of the cases decided under the religion clauses prior to Everson v. Board of Educ., 330 U.S. 1 (1947), involved the regulation of proselytising, see, e.g., Murdock v. Pennsylvania, 319 U.S. 105 (1943) (distribution of religious literature); consequently, they often implicated free speech considerations. In the last 40 years, litigation based on the religion clauses has proliferated, much of it concerning general welfare legislation. See, e.g., Sherbert v. Verner, 374 U.S. 
Professor Kurland has argued that the tension between the two clauses must be resolved in favor of strict neutrality: Government may not use any religious classifications either to confer a benefit or to impose a burden on religion. ${ }^{28}$ An implication of his view is that the free exercise clause does not justify granting religious exemptions from otherwise valid legislation. ${ }^{29}$

Other commentators have argued that Professor Kurland ignores the preferred position that the Constitution confers on religious exercise through the free exercise clause. ${ }^{30}$ The Supreme Court has never espoused a strictly neutral interpretation of the clauses; rather, it has regularly construed the free exercise clause to exempt religious exercise from burdensome legislation even though such exemptions in some sense benefit religion. ${ }^{31}$ The approach reflected in exemption doctrine can be characterized as benign neutrality. In situations where government must choose between infringing upon or facilitating religious exercise, the free exercise clause requires that, absent an overriding governmental interest, government choose the latter course.

398 (1963) (exempting under free exercise clause Sabbatarian from legislation conditioning receipt of unemployment compensation benefits on willingness to work on sabbath); Everson, 330 U.S. 1 (upholding under establishment clause state transportation of children to parochial schools); and, more recently, Bowen v. Roy, 106 S. Ct. 2147 (1986) (state's use of child's Social Security number permitted under free exercise clause even though such use violates parents' religious beliefs); Aguilar v. Felton, 105 S. Ct. 3232 (1985) (striking down remedial aid program for parochial school students).

In many cases, the Court has been aware of the tension. See, e.g., Zorach, 343 U.S. at 313; Everson, 330 U.S. at 16. As one commentator has observed, most establishment problems can be cast in free exercise terms and vice versa. Johnson, Concepts and Compromise in First Amendment Religious Doctrine, 72 CaLIF. L. Rev. 817, 821-25 (1984).

28. Kurland, supra note 19 , at 6 .

29. Choper, supra note 19, at 688-89; see also Kurland, The Irrelevance of the Constitution: The Religion Clauses of the First Amendment and the Supreme Court, 24 VILL. L. REv. 3, $16-17$ (1978) (Supreme Court has failed to reconcile exemption doctrine with nonestablishment mandate).

30. See Choper, supra note 19, at 688-89; see also Moore, supra note 19, at 196 (religion clauses' purpose to maximize religious freedom justifies exemptions).

31. See, e.g., Sherbert v. Verner, 374 U.S. 398 (1963). The decision allowed Mrs. Sherbert to refuse jobs that required Saturday work without losing unemployment benefits. In contrast, persons who might have nonreligious reasons for preferring not to work on Saturdays had to be willing to accept Saturday work. Id. at 422 (Harlan, J., dissenting); see also Abington School Dist. v. Schempp, 374 U.S. 203, 247 (1963) (Brennan, J., concurring) ("[T]he logical interrelationship between the Establishment and Free Exercise Clauses may produce situations where an injunction against an apparent establishment must be withheld in order to avoid infringement of rights of free exercise."). Justice Stevens, however, disapproves of exemptions under the free exercise clause because of their potential for violating the establishment clause. See Goldman v. Weinberger, 106 S. Ct. 1310, 1316 (1986) (Stevens, J., concurring) (opposing exemption from Air Force regulations for yarmulke wearer as engendering religious favoritism); United States v. Lee, 455 U.S. 252, 263 n.2 (1981) (Stevens, J., concurring) (establishment clause seeks to avoid risk that exemption will be perceived as favoring one religion over another). 


\section{B. Direct and Indirect Burdens on Religious Exercise: Braunfeld v. Brown Revisited}

With the vast expansion of governmental regulation of health, safety, welfare, and morals the state necessarily impinges on religious belief and practice. Compulsory vaccination requirements, for example, violate some religious beliefs. ${ }^{32}$ Requiring parochial school instructors to meet teacher certification requirements increases the costs of religious education. Distinguishing which of these infringements of religious freedom must give way to the constitutional guarantee of free exercise, from those which need not, has been a central challenge of the Court's free exercise jurisprudence.

In Braunfeld v. Brown, ${ }^{33}$ the Court resolved this difficult task by distinguishing direct from indirect burdens on religious exercise. ${ }^{34}$ Although the Court has not relied on the distinction in subsequent free exercise cases, ${ }^{35}$ it provides an analytic framework to separate occasions when government may be required to accommodate an adherent's religious exercise from those when government is not required but may be permitted to accommodate religious exercise. $^{38}$

32. See, e.g., Jacobson v. Massachusetts, 197 U.S. 11 (1905).

33. 366 U.S. 599 (1961).

34. Id. at 606-07.

35. See, e.g., Sherbert v. Verner, 374 U.S. 398, 403 (1963). On the Court's later reading of Braunfeld, government must accommodate religious exercise significantly burdened either directly or indirectly by government action, absent an overriding governmental interest in enforcing the legislation. See id. at 403, 408-09; Thomas v. Review Bd., 450 U.S. 707, 717-18 (1981). In Sherbert, the Court characterized the Braunfeld holding as a refusal to extend mandated free exercise protection to the indirect burden on religious exercise caused by a Sunday Closing Law, on the ground that the state had established a strong interest in a uniform day of rest. Sherbert, 374 U.S. at 408 . This Note, in contrast, argues that Sherbert and its progeny expanded the meaning of direct burdens on religious exercise. See infra text accompanying notes $41-43$. While the indirect/direct distinction may appear merely semantic, it has significant ramifications for free exercise analysis. Under the Court's construction, the distinction between indirect and direct burdens carries no analytic import; the test applied to either type of burden is whether a compelling state interest exists that outweighs the burdened free exercise interest. If not, the religious interest must be accommodated. See, e.g., Sherbert, 374 U.S. at 403.

Although the Court did not rely on the direct/indirect distinction, last term, in Bowen v. Roy, 106 S. Ct. 2147 (1986), it held that certain free exercise claims were not cognizable under the free exercise clause. The plaintiff in Bowen argued that the government's use of a Social Security number for his daughter infringed his free exercise of religion, because he believed that such use would impair his daughter's spirit. Id. at 2152. The Court held that his claim did not fall within the protection of the free exercise clause. Id. Under this Note's analysis, in contrast, the government's use of the number indirectly burdens the plaintiff's religious beliefs; consequently, the government is not required, but may be permitted, to accommodate the belief. See infra text accompanying notes 45-53. For further discussion of Bowen, see infra note 58.

Several lower courts have recently revived the line drawn in Braunfeld to distinguish free exercise claims that require accommodation from those that do not. See, e.g., Lakewood, Ohio Congregation of Jehovah's Witnesses, Inc. v. City of Lakewood, 699 F.2d 303, 305-06 (6th Cir.), cert. denied, 464 U.S. 815 (1983); Congregation Beth Yitzchok, Inc. v. Town of Ramapo, 593 F. Supp. 655, 659 (S.D.N.Y. 1984).

36. The usefulness of the distinction was pointed out to me by Professor Perry Dane. It is implicit 
A law imposes a direct burden on an adherent's religious exercise if, as applied to the adherent, its operation turns on the adherent's disavowal of a religious belief or abandonment of a religious practice. Thus, legislation imposes a direct burden when it requires a religious adherent to engage in actions forbidden by his or her faith, ${ }^{37}$ or prohibits actions required by his or her faith. ${ }^{38}$ For example, application of a narcotics law to native Americans who subscribe to Peyotism constitutes a direct burden on their religious exercise. ${ }^{3 \theta}$ The law's prohibition of the use of peyote conflicts with the religious dictates prescribing its use. ${ }^{40}$

In addition, legislation that conditions the receipt of generally available benefits upon the disavowal of religious beliefs or abandonment of religious practices directly burdens religious exercise. For example, legislation that conditions the availability of unemployment benefits on an applicant's willingness to work on Saturdays imposes a direct burden on the religious exercise of Sabbatarians. ${ }^{41}$ Like the application of the narcotics law to adherents of Peyotism, the application of the unemployment benefit requirements to Sabbatarians turns on their renouncing their religious faith. ${ }^{42}$ Legislation thus imposes a direct burden on religious exercise through its formal interaction with the dictates of religion. When legislation directly burdens an adherent's religious exercise, the free exercise clause requires government to exempt the adherent from the legislation, unless a compelling governmental interest overrides the adherent's free exercise interest. 43

Legislation imposes an indirect burden on religious exercise when it contributes to the economic or social costs of religious adherence. The Sunday Closing Law at issue in Braunfeld exemplifies such legislation. Braunfeld and the other appellants, Orthodox Jewish merchants, sought an exemption from a Sunday Closing Law. ${ }^{44}$ They argued that the law

in the characterization of an exemption claim as a claim based on a conflict between the demands of religious faith and civil legal requirements. See Note, Religious Exemptions Under the Free Exercise Clause: A Model for Competing Authorities, 90 YALE L.J. 350 (1980) (proposing conflicts of law model to resolve exemption claims).

37. See, e.g., Wisconsin v. Yoder, 406 U.S. 205, 211 (1972) (exempting Amish from educational requirements that conflicted with their religious beliefs).

38. See, e.g., People v. Woody, 61 Cal. 2d 716, 394 P.2d 813, 40 Cal. Rptr. 69 (1964).

39. Id.

40. Id. at 720-22, 394 P.2d at 817-18, 40 Cal. Rptr. at 73-74.

41. Cf. Sherbert v. Verner, 374 U.S. 398 (1963) (Sabbatarian exempt from statute conditioning unemployment benefits on willingness to work on Saturdays); Thomas v. Review Bd., 450 U.S. 707 (1981) (Jehovah's Witness cannot be denied unemployment benefits based on termination for "good cause" when job terminated for refusal, on religious grounds, to engage in weapons production).

42. Sherbert, 374 U.S. at 404.

43. Cf. Thomas, 450 U.S. at 717-18; Sherbert, 374 U.S. at 403 . But see Bowen v. Roy, 106 S. Ct. 2147, 2154-58 (1986) (plurality decision) (emphasizing difference between statutes penalizing religious beliefs and those conditioning benefits on disavowal of religious beliefs; applying lower standard to latter).

44. Sunday Closing Laws were upheld under the establishment clause in a companion case, Mc- 
burdened the free exercise of their religion, which required them to refrain from work on Saturdays. ${ }^{45}$ The Sunday Closing Law put them at a severe economic disadvantage in relation to merchants who could conduct business six days a week, in effect compelling them to choose between adherence to their faith and economic survival. ${ }^{46}$ The law did not impose a requirement that formally contradicted the dictates of Judaism; rather, it was a factor that contributed to the cost of the appellants' religious adherence. ${ }^{47}$ But for the competitive nature of the retail business, the legislation would not have had any consequences for their religious exercise. Because the burden was caused by the interaction of the statute and the prevailing economic conditions, it could be described as incidental to the legislation. Such a characterization, however, should not detract from appreciation of the severity of the cost involved: Braunfeld alleged that the Sunday Closing Law would force him to go out of business. ${ }^{48}$

The Supreme Court held that the free exercise clause did not require Pennsylvania to exempt the Braunfeld appellants from the Sunday Closing Law. ${ }^{49}$ The Court, however, did not appeal to establishment clause limitations on the free exercise guarantee that rendered such an exemption invalid; ${ }^{60}$ rather, it strongly suggested that Pennsylvania would have been permitted to incorporate an exemption for Sabbatarians into the statute, had it so chosen. ${ }^{\text {II }}$ Noting that a number of states provide such exemptions, it suggested that an exemption might be a "wiser solution to the problem." forcement and entanglement problems, that might prompt a legislature to withhold an exemption. ${ }^{53}$ The Court thus viewed the propriety of an exemption as a question best left to the discretion of the legislature.

The Sunday Closing Law at issue in Braunfeld resulted in an economic cost to the plaintiffs' religious exercise. Zoning ordinances ${ }^{54}$ and the taxation of religious institutions ${ }^{55}$ may also impose financial burdens on religious exercise. Indirect burdens on religious exercise are not, however,

Gowan v. Maryland, 366 U.S. 420 (1961).

45. See Braunfeld v. Brown, 366 U.S. 599, 608 (1961).

46. Id. at 601-02.

47. The appellants' stated that the Sunday Closing Law would impair their ability to earn a livelihood. $I d$. at 601 .

48. Id.

49. Id. at 608-09.

50. Id.

51. Id. at 608 .

52. Id.

53. Id. at 608-09.

54. See, e.g., Lakewood, Ohio Congregation of Jehovah's Witnesses, Inc. v. City of Lakewood, 699 F.2d 303, 307-08 (6th Cir.) (free exercise clause does not require exemption from zoning ordinance that increased cost of acquiring land zoned to permit church construction), cert. denied, 464 U.S. 815 (1983).

55. Braunfeld, 366 U.S. at 606. 
limited to economic effects. A statute requiring the slaughter of animals by certain prescribed methods could effectively rule out the consumption of meat by persons whose religion dictated alternative methods. Although the statute would not compel such persons to eat meat, it would force them to choose between consuming meat and observing their faith. ${ }^{.8}$

Finally, government's actions may impose an indirect burden on an adherent's beliefs. For example, commercial development of governmentowned land containing Native American sacred religious sites places an indirect burden on the religious beliefs of adherents of religions that hold these sites sacred. ${ }^{57}$ Similarly, the government's use of social security numbers may burden a Native American's belief that such use impairs his or her spirit..8

Braunfeld's delimitation of mandated government accommodations to legislation directly burdening religious exercise did not derive strictly from either the nonestablishment mandate or from the free exercise guarantee. ${ }^{68}$ Rather, the distinction between direct and indirect burdens corresponds broadly to practical limitations $s^{80}$ on courts' capacity to manage full en-

56. In recognition of Jewish and other religious dietary restrictions, the Humane Methods of Slaughter Act exempts ritual slaughter. 7 U.S.C. $\$ \S 1902,1906$ (1982). The Act was upheld against establishment challenge in Jones v. Butz, 374 F. Supp. 1284 (S.D.N.Y.), affd, 419 U.S. 806 (1974).

57. See Wilson v. Block, 708 F.2d 735, 742 (D.C. Cir.) (commercial development of Hopi and Navajo sacred sites, which is "inconsistent with the plaintiffs' beliefs, and will cause the plaintiffs spiritual disquiet," nevertheless not enjoined by free exercise clause), cert. denied, 464 U.S. 956 (1983). But see Northwest Indian Cemetery Protective Ass'n v. Peterson, 764 F.2d 581, 585-86 (9th Cir. 1985) (free exercise protection encompasses indirect burdens on site-specific religions created by development of land). Such development does not usually involve governmental denial of access to sacred sites for participation in rituals required by the religion. See, e.g., Wilson, 708 F.2d at 740 . Development that imposed such an exclusion would directly burden the religious exercise of those adherents who held those sites sacred.

To characterize the development of federal lands containing sacred sites as imposing an indirect burden is not to belittle the development's devastating potential. It may result in the destruction of site-specific religions. See Note, Indian Religious Freedom and Governmental Development of Public Lands, 94 YALE L.J. 1447, 1447 (1985). The history of governmental appropriation of land inhabited by Native Americans may present a special case for full judicial enforcement of the free exercise guarantee. Even if it did not, this Note argues that the norm embodied in the free exercise clause compels legislatures to accommodate site-specific religions, despite the inability of courts to require such actions. See infra text accompanying notes 60-64.

58. See Bowen v. Roy, 106 S. Ct. 2147, 2151-53 (1986). Mr. Roy, the plaintiff, had asserted two separate free exercise claims: He argued that the government could not condition Social Security benefits upon the acquisition of a Social Security number for his daughter, because such acquisition violated his religious beliefs, and that the government, having assigned a Social Security number to his daughter, could not use it for internal purposes, because he believed this use would rob her spirit. Id. at 2151 . With regard to the first claim, the plurality adopted a variation of the traditional test, evaluating the governmental interest in requiring that applicants acquire Social Security numbers. See id. at 2156-58 (plurality opinion). The Court did not find the second claim cognizable under the free exercise clause. "The Free Exercise Clause simply cannot be understood to require the Iglovernment to conduct its own internal affairs in ways that comport with the religious beliefs of particular citizens." Id. at 2152.

59. See Braunfeld, 366 U.S. at 608-09.

60. "The list of legislation [having an indirect burden on religious exercise] is nearly limitless." Id. at 606 . Courts would be deluged with claims for excmptions from legislation indirectly burdening 
forcement of the free exercise norm. ${ }^{61}$ Legislative processes, which can accommodate competing needs of constituents by using flexibility and experimentation, are better suited to determine when and by what means indirect burdens should be alleviated. By removing indirect burdens on religious exercise, a legislature furthers the norm embodied in the free

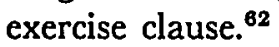

The free exercise clause's prohibition against governmental interference justifies voluntary legislative attempts to facilitate religious exercise by removing indirect governmentally imposed burdens. ${ }^{63}$ When government removes such burdens it is accommodating, rather than promoting, religion: When a statutory scheme contributes to the economic, social, or personal costs of religious exercise or belief, an accommodation alleviates such effects. ${ }^{B 4}$

Governmental accommodations of religion include statutory exemptions, such as Sunday Closing Law exemptions ${ }^{65}$ and taxation exemptions, ${ }^{68}$ as

religious exercise, for example taxation, id., and would be faced with the difficult task of evaluating in each case a series of factors whose assessment is best left to legislatures. It is an unfortunate development of free exercise doctrine that courts already engage in a balancing exercise when direct burdens on religious exercise are at issue. See Clark, Guidelines for the Free Exercise Clause, 83 HaRv. L. REv. 327, 330-44 (1969) (criticizing ad hoc nature of compelling state interest test).

61. I use the word "norm" instead of "value" to convey a conception of the free exercise clause as a constraint on government action. Free exercise values, in contrast, can encompass the actions of private individuals. Thus, Title VII's requirement that employers reasonably accommodate the religious practices of their employees, 42 U.S.C. $\$ 2000 \mathrm{e}(\mathrm{j})$ (1982), furthers free exercise values, but does not implicate the norm embodied in the free exercise clause. See infra note 64.

62. See Sager, Fair Measure: The Legal Status of Underenforced Constitutional Norms, 91 Harv. L. Rev. 1212 (1978). Professor Sager observes that courts regularly decline to uphold constitutionally based norms on the basis of institutional concerns. Id. at 1218-20. He argues:

[C]onstitutional norms which are underenforced by the federal judiciary should be understood

to be legally valid to their full conceptual limits, and federal judicial decisions which stop short

of these limits should be understood as delineating only the boundaries of the federal courts'

role in enforcing the norm: By 'legally valid,' I mean that the unenforced margins of under-

enforced norms should have the full status of positive law which we generally accord to the

norms of our Constitution, save only that the federal judiciary will not enforce these margins. Id. at 1221 .

63. Wallace v. Jaffree, 472 U.S. 38, 83 (1985) (O'Connor, J., concurring in the judgment).

64. See id. According to the analysis offered in this Note, Title VII's requirement that employers reasonably accommodate the religious practices of their employees, 42 U.S.C. $\S 2000 \mathrm{e}(\mathrm{j})(1982)$, is not a governmental accommodation of religion because it does not remove governmentally imposed burdens on religious exercise. The provision thus cannot be justified on the ground that it constitutes legislative enforcement of the norm embodied in the free exercise clause, because that norm is limited to government action. See Thornton v. Caldor, 472 U.S. 703, 712 (1985) (O'Connor, J., concurring) (Title VII "not the sort of accommodation statute specifically contemplated by the Free Exercise Clause").

65. E.g., Ky. Rev. Stat. ANN. $\$ 436.160$ (2) (Baldwin 1985) (exempting Sabbatarians from Sunday Closing Law), upheld, Commonwealth v. Arlan's Dep't Store, 357 S.W.2d 708 (Ky.), appeal dismissed for want of substantial federal question sub nom. Arlan's Dep't Store v. Kentucky, 371 U.S. 218 (1962). Without discussing the establishment clause in any detail, the Kentucky Court of Appeals upheld the exemption on the ground that in Braunfeld, the Supreme Court had "by implication" upheld Sunday Closing Law exemptions. 357 S.W.2d at 710.

66. E.g., N.Y. ConST. art. XVI, $\S 1$ (exempting property used for religious, educational, or charitable purposes), upheld, Walz v. Tax Comm'n, 397 U.S. 664 (1970). The Court considered the 
well as affirmative attempts to facilitate religious exercise, such as aid to parochial schools. ${ }^{67}$ In all of these instances, the touchstone of an accommodation of religion is government's attempt to eliminate burdens imposed on individuals' free exercise of religion by government's own action. ${ }^{68}$

\section{ACCOMmOdations OF RELigion UNDER THE Establishment Clause}

That legislation accommodates religion, however, is not sufficient to establish its permissibility under the establishment clause. ${ }^{69}$ While the nonestablishment mandate does not necessarily require invalidation of governmental accommodations of religion as such, it places constraints on the means by which a particular attempt to remove governmentally imposed burdens on religion may be carried out. ${ }^{70}$

\section{A. Permissibility of Government's Attempts to Accommodate}

In Lemon v. Kurtzman, ${ }^{71}$ the Supreme Court construed the nonestablishment mandate to require that a law (1) have a secular purpose; (2) have a primary effect that neither advances nor inhibits religion; and (3) not lead to excessive governmental entanglement with religion. ${ }^{72}$ Literal application of the secular purpose and neutral primary effect prongs of the Lemon test would clearly invalidate any accommodation of religion,

secular purpose of the exemption, the lengthy history of church tax exemptions, and the potential for greater entanglement in taxing churches in its determination of the exemption's constitutionality. See id. at $672-80$.

67. E.g., 1974 N.Y. Laws ch. 507, as amended by ch. 508 (1974) (reimbursing parochial schools for costs of state-mandated exams), reproduced in N.Y. Educ. LAw $\$ 3601$ historical note (McKinney 1981), upheld, Committee for Pub. Educ. \& Religious Liberty v. Regan, 444 U.S. 646 (1980).

68. The governmentally sponsored crèche upheld in Lynch v. Donnelly, 465 U.S. 668 (1984), was not the result of an attempt to remove governmentally imposed burdens on religious exercise; consequently, it does not constitute an accommodation of religion under the definition advanced in this Note. The crèche may be justifiable by an "acknowledgment" exception to the nonestablishment mandate. See id. at 676-77 (listing illustrations of "Iglovernment's acknowledgment of our religious heritage").

69. Wallace v. Jaffree, 472 U.S. 38, 82 (1985) (O'Connor, J., concurring in the judgment) ("IJ]udicial deference to all legislation that purports to facilitate the free exercise of religion would completely vitiate the Establishment Clause.").

70. See infra text accompanying notes 74-76.

71. 403 U.S. 602 (1971).

72. Id. at 612-13. Under the "secular purpose" requirement, the Court has invalidated legislation providing for the posting of the Ten Commandments in public school classrooms. Stone v. Graham, 449 U.S. 39 (1980).

Under the "primary effect" prong, the Court has struck down maintenance and repair grants to parochial schools. Committee for Pub. Educ. \& Religious Liberty v. Nyquist, 413 U.S. 756, 774-80 (1973).

The Court has relied on Lemon's third prong, the prohibition against excessive governmental entanglement with religion, to invalidate a Massachusetts statute that authorized a church to block operating licenses for liquor stores located within 500 feet of the church. Larkin v. Grendel's Den, Inc., 459 U.S. 116 (1982). 
because every accommodation, qua accommodation, has a religious purpose and a primary effect that advances religion. ${ }^{\mathbf{7 3}}$

Such a mechanical application of Lemon, however, disregards the protected status that the free exercise clause bestows on religious exercise. ${ }^{74}$ In this interpretation of the Lemon requirements, the free exercise clause itself lacks a secular purpose and has the primary effect of advancing religion. ${ }^{78}$ Therefore, to determine whether an accommodation violates the establishment clause it is necessary to focus on the means through which a particular accommodation is effected rather than on the accommodation per se. ${ }^{76}$

\section{B. Assessing the Permissibility of a Particular Accommodation of Religion: Lemon Reconsidered}

The Lemon test has attracted sharp criticism both inside ${ }^{77}$ and outside ${ }^{78}$ the Court. The criticisms focus mainly on the ad hoc results to which the test gives rise ${ }^{79}$ and on the test's tendency to obscure the privileged status that the religion clauses accord religious liberty. ${ }^{80}$ Despite these criticisms, Justice O'Connor, who is committed to the continued viability of Lemon, has revised the first two prongs to proscribe legislation having the purpose or primary effect of endorsing religion. ${ }^{81}$ Justice O'Connor's insight suggests a reformulation of the Lemon standard to provide an approach to determining the permissibility of governmental accommodations of religion under the establishment clause. Insofar as this approach builds on the concerns at the core of nonestablishment doctrine and recognizes the role

73. "By definition, such legislation has a religious purpose and effect in promoting the free exercise of religion." Wallace v. Jaffree, 472 U.S. at 82 (O'Connor, J., concurring in the judgment).

74. See id. at 82-83 (O'Connor, J., concurring in the judgment); supra text accompanying notes 60-63.

75. See Johnson, supra note 27 , at 827 .

76. See Wallace v. Jaffree, 472 U.S. at 81 (O'Connor, J., concurring in the judgment) ("Establishment Clause analysis must comport with the mandate of the Free Exercise Clause that government make no law prohibiting the free exercise of religion.").

77. See, e.g., id. at 108-12 (Rehnquist, J., dissenting).

78. See, e.g., Johnson, supra note 27, at 827-29 (Lemon prongs do not determine where lines should be drawn); Schwartz, Larkin v. Grendel's Den, Inc.: The Burger Court and the Establishment Problem, 21 Hous. L. Rev. 179, 193 (1984) (Lemon test "inherently subjective"); Note, Lynch v. Donnelly: Has the Lemon Test Soured?, 19 Loy. L.A.L. Rav. 133, 142-64 (1985) (reviewing inconsistent lower court and Supreme Court applications of Lemon test to crèche challenged in Lynch v. Donnelly, 465 U.S. 668 (1984)).

79. See Wallace v. Jaffree, 472 U.S. at 108 (Rehnquist, J., dissenting) (secular purpose prong "mercurial in application"); Schwartz, supra note 78, at 193 \& n.89 ("Absolute certainty in constitutional interpretation is neither possible nor particularly desirable. When, however, the Court uses a test that requires it to divine legislative motives, to discern a program's 'primary' effect, and to calculate whether that program would create 'excessive' entanglement, its decisions inevitably result in absolute uncertainty regarding the meaning of the Constitution.").

80. See, e.g., McConnell, supra note 19, at 3 (juxtaposing Supreme Court's continued rigid reliance on Lemon with attempts to articulate new approaches grounded in religious liberty).

81. Lynch v. Donnelly, 465 U.S. 668, 690 (1984) (O'Connor, J., concurring). 
of accommodations in furthering free exercise, it provides a standard capable of consistent application and avoids the criticism levelled against the Lemon test. Under this Note's approach, a governmental accommodation of religion does not violate the establishment clause, if (1) its purpose is to remove a government imposed burden on religious exercise; (2) in effect, it neither endorses religion, provides financial support to religious exercise, nor imposes the affirmance of religious beliefs; and (3) it does not excessively entangle government with religion. ${ }^{82}$

\section{Assessing the Purpose of an Accommodation}

As argued above, invalidating an accommodation of religion because its purpose is manifestly non-secular overlooks the accommodation's importance in furthering free exercise. Rather than attempting to ascribe a secular purpose to the legislation at issue, ${ }^{83}$ the inquiry under the purpose prong should focus on whether the legislation is designed to remove governmentally imposed burdens on religious exercise. Identification of a religious belief or practice that, absent the accommodative legislation at issue, is at risk of being indirectly burdened by other governmental action should normally be sufficient to legitimate the purpose of the challenged legislation. Should the history of the legislation indicate that, despite its purported purpose, its central function is to endorse religion, the legislation should be struck down. ${ }^{84}$

In Wallace v. Jaffree, ${ }^{85}$ for example, Justice O'Connor considered whether the statute at issue, which provided for a moment of silence in school to be used for meditation or prayer, could be characterized as an accommodation rather than as an endorsement of religion. ${ }^{86}$ Observing that there was no religious practice at risk of being burdened through government action because Alabama law already called for a moment of silence, ${ }^{87}$ she concluded that the statute's purpose was to endorse religion

82. The three components proposed in this Note do not necessarily exhaust all impermissible governmental involvements with religion. For example, an additional nonestablishment principle not easily subsumed under those discussed is the requirement that government not use religious means to realize governmental ends. See Abington School Dist. v. Schempp, 374 U.S. 203, $280-81$ (1963) (Brennan, J., concurring). This Note focuses on these three factors because they represent central principles of nonestablishment jurisprudence that are likely to function in the accommodation context.

83. The attempt to devise a secular purpose for an accommodation of religion may obscure its role in removing governmentally imposed burdens on religious exercise, and, consequently, may confuse the inquiry concerning its permissibility under the establishment clause. This inquiry should focus directly on the accommodation's success in removing such burdens. See Wallace v. Jaffree, 472 U.S. at 83 (O'Connor, J., concurring in the judgment) ("disingenuous to look for a purely secular purpose" of an accommodation; religious purpose is "legitimated by the Free Exercise Clause").

84. See Wallace v. Jaffree, 472 U.S. at 60 (opinion of the Court).

85. 472 U.S. 38 (1985).

86. Id. at 83-84 (O'Connor, J., concurring in the judgment).

87. Id. 
impermissibly. ${ }^{88}$ She emphasized, however, that the Court's holding did not necessarily apply to the moment of silence statutes of other states. ${ }^{80}$ The permissible purpose requirement would be satisfied with respect to such statutes upon a showing that, absent statutory protection, some religious belief or practice would be burdened by governmental action.

\section{Assessing the Primary Effect of an Accommodation}

The voluntary nature of religious exercise is imperiled when government confers its official imprimatur on religion, ${ }^{90}$ when tax revenues are used to support religious activities, ${ }^{91}$ or when government requires the affirmance or disaffirmance of religious beliefs. ${ }^{92}$ The neutral primary effect requirement provides that an accommodation may not mandate the profession of religious beliefs, endorse religion, or provide direct financial support to religion. ${ }^{93}$ It ensures that the effects of an accommodation not extend beyond the purpose of removing governmentally imposed burdens.

88. Id. at 84 .

89. Justice O'Connor stated: "The Court holds only that Alabama has intentionally crossed the line between creating a quiet moment during which those so inclined may pray, and affirmatively endorsing the particular religious practice of prayer." Id. The Court this term granted certiorari to consider the constitutionality of a New Jersey moment of silence statute. Karcher v. May, 55 U.S.L.W. 3507 (U.S. Jan. 27, 1987), granting cert. from May v. Cooperman, 780 F.2d 240 (3d Cir. 1985).

90. Justice O'Connor identifies governmental endorsement of religion and entanglement with religion as the two dangers against which the establishment clause is intended to guard. Lynch v. Donnelly, 465 U.S. 668, 687-88 (1984) (O'Connor, J., concurring). Endorsement of religion infringes on the religious liberty of nonadherents by making religious adherence "relevant to a person's standing in the political community." Wallace v. Jaffree, 472 U.S. at 69 (O'Connor, J., concurring in the judgment). It conveys a message to nonadherents that they are "outsiders." Conversely, it confers a preferred status on adherents. Id. (citing Lynch v. Donnelly, 465 U.S. at 688). The Court relied on the endorsement principle in Wallace v. Jaffree to strike down an Alabama statute sanctioning a moment of silence in schools. 472 U.S. at 60.

91. See Marsh v. Chambers, 463 U.S. 783, 803 (1983) (Brennan, J., dissenting).

92. Torcaso v. Watkins, 367 U.S. 488, 495 (1961).

93. The neutral primary effect requirement has received the Court's most sustained attention in the cases concerning aid to sectarian schools. See, e.g., Committee for Pub. Educ. \& Religious Liberty v. Regan, 444 U.S. 646 (1980); Wolman v. Walter, 433 U.S. 229 (1977); Meek v. Pittenger, 421 U.S. 349 (1975); Committee for Pub. Educ. \& Religious Liberty v. Nyquist, 413 U.S. 756 (1973).

Although the Court never explicitly embraced the position in the "aid to parochial school" cases that the issue of primary effect involved endorsement and financial support, the factors that it considered salient to its inquiry under the primary effect prong reveal these related concerns. Among the considerations relevant to the Court's evaluation of whether government aid had the primary effect of advancing religion were the form of aid, compare Wolman v. Walter, 433 U.S. 229, 241-44 (1977) (upholding provision of diagnostic services) and Board of Educ. v. Allen, 392 U.S. 236 (1968) (upholding state book grants) with Levitt v. Committee for Pub. Educ. \& Religious Liberty, 413 U.S. 472 (1973) (striking down direct governmental reimbursement to schools), and the recipient of the aid, compare Mueller v. Allen, 463 U.S. 388 (1983) (upholding tax deduction to parents for tuition expenses) with Levitt v. Committee for Pub. Educ. \& Religious Liberty, 413 U.S. 472 (1973) (striking down governmental reimbursement to schools).

Aid that clearly extended the benefits of public welfare to private individuals and was tailored to facilitate their choices was less suspect than direct financial aid to religious schools, which had the appearance of endorsing the religious mission of the schools by putting governmental funds collected from individual taxpayers at the schools' disposal. Compare Mueller v. Allen, 463 U.S. 388 (1983) 


\section{a. Endorsement}

Determining whether an accommodation impermissibly endorses religion requires "judicial interpretation of social facts." an informed assessment of the historical context giving rise to the accommodation..$^{98}$ Legislation written in religiously neutral terms ${ }^{98}$ and tailored to enhance the choices of private individuals avoids the appearance of endorsement. ${ }^{97} \mathrm{An}$ accommodation should convey the message that it is treating religious adherents differently only in order to remove governmentally imposed burdens.

\section{b. Financial Aid}

Financial support usually signifies endorsement. Nevertheless, even if it were possible for government to provide financial aid without endorsing religion, such support might still violate the establishment clause. Irre-

(upholding tax deductions for tuition expenses) with Levitt v. Committee for Pub. Educ. \& Religious Liberty, 413 U.S. 472 (1973) (striking down state reimbursements to schools for expenses incurred in administering state-required exams).

94. Lynch v. Donnelly, 465 U.S. 668, 694 (1984) (O'Connor, J., concurring).

95. "The relevant issue is whether an objective observer, acquainted with the text, legislative history, and implementation of the statute, would perceive it as a state endorsement . . ." Wallace v. Jaffree, 472 U.S. 38, 76 (1985) (O'Connor, J., concurring in the judgment).

Justice O'Connor's focus on the perspective of the "objective observer" is problematic given her characterization of endorsement. In her view, endorsement creates disparities between the experiences of religious adherents and nonadherents. Consequently, a neutral ground for evaluation may be impossible. A solution is to judge governmental endorsement of religion by adopting the perspective of the reasonable nonadherent. See, e.g., Friedman v. Board of County Comm'rs, 781 F.2d 777, 781-82 (10th Cir. 1985) (considering rabbi's and other non-Christians' impressions of cross depicted on county seal to infer that seal impermissibly endorsed religion), cert. denied, $106 \mathrm{~S}$. Ct. 2890 (1986). Justice O'Connor's failure to engage in such an exercise may have contributed to her inability to perceive the endorsement of Christianity that others would see as inherent in the crèche at issue in Lynch v. Donnelly, 465 U.S. at 692 (O'Connor, J., concurring) (upholding state-funded crèche under establishment clause); see id. at 701-02 (Brennan, J., dissenting) ("The effect on minority religious groups, as well as on those who may reject all religion, is to convey the message that their views are not [as] worthy of public recognition [as the views of those believing in the message of the nativity] nor entitled to public support.").

96. See Thornton v. Caldor, 472 U.S. 703, 711 (1985) (O'Connor, J., concurring) (statute conferring on employees right not to work on their sabbath impermissibly endorses sabbath observance); id. at 711-12 (objective observer would perceive Title VII's reasonable accommodation requirement as antidiscrimination law rather than as endorsement of religion or of particular religious practices, in part because requirement extends to all beliefs and practices).

However, legislation referring to a specific religion does not necessarily endorse that religion impermissibly. The historical context and the implementation of the legislation may militate against the appearance of endorsement. See, e.g., The Humane Methods of Slaughter Act, 7 U.S.C. $\S 1902$ (b) (1982) (exempting slaughter "in accordance with the ritual requirements of the Jewish faith or any other religious faith that prescribes a method of slaughter whereby the animal suffers [instantaneous] loss of consciousness").

97. Mueller v. Allen, 463 U.S. at 399 ("[w]here, as here, aid to parochial schools is available only as a result of decisions of individual parents, no 'imprimatur of state approval' . . . can be deemed to have been conferred on any particular religion, or on religion generally." (citation omitted)). 
spective of whether government is placing its imprimatur on religion, government may not finance religious exercise. ${ }^{98}$

In determining the validity of financial support ${ }^{99}$ the Court has drawn a line between programs that subsidize religious operations and programs that, by funding the secular activities of a religious institution, effectively permit the institution to devote greater resources to its religious activities. ${ }^{100}$ Government's legitimate interest in the secular activities of religiously affiliated institutions is sufficient to justify government funding of those activities as long as the funded secular activities are separate from the institutions' religious activities ${ }^{101}$ and the program does not impermissibly endorse religion ${ }^{102}$ nor impose religious beliefs. ${ }^{103}$ Consequently, accommodations of religion may not involve government subsidies to religious institutions unless such subsidies are in furtherance of legitimate governmental interests other than the interest in accommodation. ${ }^{104}$

98. See Marsh v. Chambers, 463 U.S. 783, 803 (1983) (Brennan, J., dissenting). Regardless of whether taking an individual's money to fund religious practice impermissibly influences such an individual to conform, it constitutes a direct injury to conscience. Id.; see also Gilfillan v. City of Philadelphia, 637 F.2d 924, 931 (3d Cir. 1980) ("regardless of imprimatur," Philadelphia's construction of stage for Pope's visit had "unique" religious effect in that it "effectively enabled the Pope to reach large numbers of persons and to perform a religious service"), cert. denied, 451 U.S. 987 (1981); Schwartz, supra note 78, at 194-205 (proposing separate establishment tests for doctrinal and financial support).

99. The question of financial subsidy is distinct from the question of tax exemptions for religious institutions, even though the latter "necessarily operate to afford an indirect benefit." Walz v. Tax Comm'n, 397 U.S. 664, 674-75 (1970) (upholding property tax exemption for churches). " '[[I]]n the case of direct subsidy, the state forcibly diverts the income of both believers and nonbelievers to churches,' while 'fi]n the case of an exemption, the state merely refrains from diverting to its own uses income independently generated by the churches through voluntary contributions." "Id. at 691 (Brennan, J., concurring) (quoting Gianella, Religious Liberty, Nonestablishment, and Doctrinal Development Part II: The Nonestablishment Principle, 81 HARv. L. REv. 513, 553 (1968)). In his majority opinion, Chief Justice Burger traces the lineage of the numerous existing tax exemptions to the traditional prohibition of financial involvement between government and churches. "The hazards of churches supporting government are hardly less in their potential than the hazards of government supporting churches." Walz, 397 U.S. at 675. See generally Bittker, Churches, Taxes and the Constitution, 78 YALE L.J. 1285 (1969) (criticizing assumptions underlying argument that tax exemptions for churches are establishment of religion).

100. See Hunt v. MCNair, 413 U.S. $734,742-43$ (1973). The proposition that all financial aid to religion is impermissible, premised as it is on a conception of the fungibility of resources, has been consistently rejected by the Court. See id.; Tilton v. Richardson, 403 U.S. 672, 679 (1971). Tilton involved federal construction grants to church-affiliated colleges and universities for facilities devoted to secular functions. Invalidating the program on the ground that it freed institutional resources for the construction of buildings dedicated to religious worship would have required the assumption that the institutions involved would not have undertaken the construction of religious buildings without the financial aid to the secular construction program. This assumption, however, is questionable: Without the funding, the institutions' priorities might have led them, on the contrary, to build buildings devoted to religious activities while forsaking other secular construction.

101. See, e.g., Levitt v. Committee for Pub. Educ. \& Religious Liberty, 413 U.S. 472, 480 (1973) (funding for governmentally mandated testing impermissible because aid "devoted to secular functions ... not identifiable and separable from aid to sectarian activities").

102. See supra notes 94-97 and accompanying text.

103. See infra notes $105-07$ and accompanying text.

104. See Committee for Pub. Educ. \& Religious Liberty v. Regan, 444 U.S. 646 (1980) (upholding reimbursement to sectarian schools for administration of state-mandated tests). Thus legislation 


\section{c. Imposed Affirmance of Religious Belief}

Although the Court has not applied it in recent cases arising under the establisment clause, a fundamental nonestablishment principle is that government may not "force a person 'to profess a belief or disbelief in any religion." "10s In Torcaso v. Watkins, for example, the Court held that Maryland's constitutional provision conditioning public office on the profession of belief in God violated the appellant's freedom of belief and religion. ${ }^{108}$ The state's exercise of force to compel affirmance of religious beliefs is a paradigmatic establishment of religion. Such compulsion has the obvious primary effect of advancing religion. ${ }^{107}$

\section{Assessing Potential for Entanglement}

The third component of the Lemon standard requires that government not become excessively entangled with religion. Application of this requirement to accommodations of religion presents no special problems. Exemptions do not risk excessive government entanglement with religion. ${ }^{108}$ If accommodations involve affirmative government actions, government may not supervise religious institutions ${ }^{109}$ or decide questions of religious practice or doctrine, which are beyond its competence. ${ }^{110}$ Conversely, accommodations may not delegate to religion control over affairs properly within the sphere of government. ${ }^{111}$

that, by subsidizing travel to church, sought to offset the effects of zoning ordinances that required adherents to live a distance from their churches would be impermissible, even if it were possible to draft such legislation to avoid the appearance of endorsement.

105. Torcaso v. Watkins, 367 U.S. 488, 495 (1961) (quoting Everson v. Illinois, 330 U.S. 1, 15 (1947)); see also West Va. Board of Educ. v. Barnette, 319 U.S. 624 (1943) (compulsory flag salute in school infringes on freedom of belief).

106. 367 U.S. at 496 .

107. Because this requirement implicates individual freedom of belief, it can be characterized as deriving from the free exercise guarantee. In fact, the Court has invoked it regularly as a free exercise principle. See, e.g., Sherbert v. Verner, 374 U.S. 398, 402 (1963). Nevertheless, insofar as the prohibition against governmental imposition of religious beliefs extends even to forcing a person to affirm religious beliefs with which he or she agrees, it captures a core nonestablishment principle.

108. See, e.g., Walz v. Tax Comm'n, 397 U.S. 664, 676 (1970) (tax exemption "creates only a minimal and remote involvement between church and state and far less than taxation of churches"). The potential for governmental entanglement in the enforcement of a statutory exemption is no greater than the entanglement that attends courts' disposition of free exercise claims for exemptions. See, e.g., Wisconsin v. Yoder, 406 U.S. 205, 216-17 (1972) (describing deep religious convictions of Amish); United States y. Kuch, 288 F. Supp. 439, 444-45 (D.D.C. 1968) (doubting sincerity of religious commitment of church whose official songs are "Puff, the Magic Dragon" and "Row, Row, Row Your Boat"). But see Welsh v. United States, 398 U.S. 333, 339 (1970) (broadly reading conscientious objector statute to cover objectors having a "sincere and meaningful belief which occupies in the life of its possessor a place parallel to that filled by the God of those admittedly qualifying for the exemption' " (quoting United States v. Seeger, 380 U.S. 163, 176 (1965))).

109. Lemon v. Kurtzman, 403 U.S. 602,619 (1971).

110. Jones v. Wolf, 443 U.S. 595, 602 (1979).

111. Larkin v. Grendel's Den, Inc., 459 U.S. 116 (1982). In Grendel's Den, the Court struck down a statute that gave churches discretion to decide whether liquor sales could occur within 500 feet 


\section{Application of the Standard to the New York Get STATUTE}

In determining whether the New York get statute is a permissible accommodation of religion, a court should ask the following questions: First, does the statute alleviate burdens on free exercise that indirectly result from legislation? Second, does the statute avoid endorsement of religion and imposition of religious beliefs? Third, does the statute avoid excessive governmental entanglement with religion?

\section{A. The New York Get Statute as an Accommodation of Religious Exercise}

\section{Marriage as a Free Exercise Right and the Burden Imposed by Civil Divorce}

The right to marry is one of the cluster of fundamental freedoms concerning familial matters accorded constitutional stature by the Supreme Court. ${ }^{112}$ Although courts have most frequently spoken of marriage as protected within a zone of privacy, ${ }^{113}$ the right to marry can involve a religious dimension which ties it more closely to the Constitution's free exercise guarantee. ${ }^{114}$ The centrality of marriage within different religious traditions is recognized by solemnization provisions in every state. Solemnization permits a couple to enter a legally binding relationship through a religious ceremony, in effect, granting civil legal status to a religious ceremony. ${ }^{116}$

In Judaism, marriage is central to religious life. ${ }^{116}$ Significant religious

of their property. The statute impermissibly gave a religious institution control over a governmental function, the licensing of liquor establishments. Id. at 126-27.

112. See, e.g., Zablocki v. Redhail, 434 U.S. 374 (1978) (statute conditioning freedom to marry on showing that support obligations to minor children have been met violates due process); Loving v. Virginia, 388 U.S. 1, 12 (1967) (miscegenation laws interfere with fundamental right to marry protected by due process clause); see also Pierce v. Society of Sisters, 268 U.S. 510 (1925) (upholding parents' right to send children to private school).

113. See Griswold v. Connecticut, 381 U.S. 479 (1969).

114. But see Reynolds v. United States, 98 U.S. 145 (1879) (free exercise does not require Mormon exemption from statute prohibiting bigamy). Reynolds relied on a distinction, subsequently abandoned, between beliefs, which were protected under the free exercise clause, and actions, which were not, id. at 164, 166-67. See Wisconsin v. Yoder, 406 U.S. 205, 219-20 (1972).

115. See, e.g., N.Y. Dom. Rel. Law § 11(1) (McKinney 1977); Wis. Stat. ANN. § 765.16(1)-(3) (West 1981); $c f$. Wolfe v. Wolfe, 76 Ill. 2d 92, 389 N.E.2d 1143 (1979) (annulling marriage on basis of fraud affecting essentials of marriage). In Wolfe, the defendant deceived the plaintiff, a devout Catholic, into marrying her by telling him that her first husband had passed away. The court held that this fraud affected the essentials of the marriage and made the defendant unable to continue to perform marital duties and obligations. Wolfe reflects the court's view that religious commitment is often an essential aspect of a marriage.

116. The obligation to marry arises from the obligation to be fruitful and multiply. Genesis 1:28. See M. Maimonides, Mishnah TORAh, Book of Women 93-95 (I. Klein trans. 1972) (Laws Concerning Marriage Ch. XV, $\S \S 1-7) 1$ M. Maimonides, Sefer Ha-Mitzvot 228-30 (C. 
obligations that are fulfilled within the domestic sphere devolve upon the observant Jewish woman. ${ }^{117}$ Because freedom to enter into a Jewish marriage is important to a Jewish woman's religious observance, it falls within the protection of the free exercise clause.

Prior to the enactment of the get statute, civil divorce indirectly burdened the right to marry within Judaism of women whose husbands obtained civil divorces without giving gets to their wives. Civil divorce did not condition a legal result on their nonadherence to Judaism, ${ }^{118}$ but, like the legislation challenged in Braunfeld, it contributed to the cost of such adherence. ${ }^{119}$ Civil divorce impeded some women's ability to marry within Judaism because their former husbands desired to change their civil marital status but were unwilling to procure Jewish divorces. The inability to remarry within Judaism can thus be described as an indirect effect ${ }^{120}$ of civil divorce; the state's attempt to offset this effect constitutes an accommodation of religion. ${ }^{121}$

\section{Operation of the Statute}

The get statute requires a party filing for divorce to remove all barriers within his or her power to the other party's marriage, as such barriers are

Chavel trans. 1967) (Positive Commandment 212). For the importance of marriage in Judaism, see M. LAMM, supra note 1 , at 120.

117. Having developed within a male perspective, Jewish law does not impose a positive obligation specifically on women to marry. Nevertheless, some sages argued that the duty to procreate devolves on women as well as men. See The Babylonian Talmud, Tractate Yebamoth 65a-65b. Moreover, the three obligations that define Jewish observance for women, lighting of the Sabbath candles (Shabbat), proper preparation of the bread (Hallah), and family purity (Niddah), see id., Tractate Shabbat 31b, presume the state of marriage. In contemporary Orthodoxy a woman's primary religious responsibility is to develop and nurture Jewish values within the domestic sphere. See M. Meiselman, Jewish Woman in Jewish Law 16-18 (1978). Marriage is central to Conservative Judaism as well. See R. Gordis, SeX and the FamiLY In the Jewish Tradition 33 (1967) ("Judaism regards marriage and not celibacy as the ideal human state, because it alone offers the opportunity for giving expression to all aspects of human nature.")

118. See supra text accompanying notes $37-42$.

119. While Braunfeld involved economic costs imposed on religious observance, see supra notes 44-48 and accompanying text, the cost here might be characterized as social.

120. See supra text accompanying notes 48-49. The husband's refusal to grant a get is analogous to the competitive retail business in Braunfeld. Despite the get statute, husbands may still leave their wives without giving them gets, just as Sabbatarians might still have encountered ruinous competition from non-Sabbatarians, even if a Sabbatarian exception to the Sunday Closing Law had been enacted. The Sabbatarian exception would have neutralized whatever increased costs might be attributable to the Sunday Closing Law. Similarly, the get statute neutralizes whatever contributory role civil divorce has in the agunah problem. While this role, of course, cannot be measured, the availability of civil divorce may increase men's propensity to withhold a get because the procurement of a civil divorce lends a sufficient air of legitimacy to what would otherwise be desertion.

121. Some critics argue that the get statute attempts to solve a problem created by Jewish law, which only Jewish law is equipped to resolve. See, e.g., Kochen, supra note 16, at 1. This argument misconstrues the statute, which addresses the problem only to the extent that it may be exacerbated by the availability of civil divorce. Husbands who abandon their wives but do not seek a change in their civil marital status do not fall within the reach of the statute, even though their wives will not be able to remarry under Jewish law. 
defined by the religious tradition within which the original wedding took place. ${ }^{122}$ The statute permits the cleric who originally solemnized the marriage to submit an affidavit to contest the filing party's contention that he or she has removed all barriers. ${ }^{123}$

The statute thus effectively requires husbands married under Conservative or Orthodox Jewish law, who seek civil divorces, to procure a get. Because the statute applies only when parties who were married in a religious ceremony initiate civil divorce procedures, ${ }^{124}$ it does not apply to parties who separate without seeking a legal change in their marital status. The statute thus removes only those burdens on women's right to

122. N.Y. DOM. REL. LAw \& 253(1)-(9) (McKinney 1986). The statute states:

1. This section applies only to a marriage solemnized in this state or in any other jurisdiction. ... .

2. Any party to a marriage defined in subdivision one of this section who commences a proceeding to annul the marriage or for a divorce must allege, in his or her verified complaint: (i) that, to the best of his or her knowledge, that he or she has taken or that he or she will take, prior to the entry of final judgment, all steps solely within his or her power to remove any barrier to the defendant's remarriage following the annulment or divorce; or (ii) that the defendant has waived in writing the requirements of this subdivision.

3. No final judgment of annulment or divorce shall thereafter be entered unless the plaintiff shall have filed and served a sworn statement [that, as specified in subsection two, all steps have been taken to remove all barriers to defendant's remarriage or the defendant has waived the requirements of this section].

....

6. As used in the sworn statements prescribed by this section "barrier to remarriage" includes, without limitation, any religious or conscientious restraint or inhibition, of which the party required to make the verified statement is aware, that is imposed on a party to a marriage, under the principles held by the clergyman or minister who has solemnized the marriage, by reason of the other party's commission or withholding of any voluntary act. Nothing in this section shall be construed to require any party to consult with any clergyman or minister to determine whether there exists any such religious or conscientious restraint or inhibition. It shall not be deemed a "barrier to remarriage" within the meaning of this section if the restraint or inhibition cannot be removed by the party's voluntary act. Nor shall it be deemed a "barrier to remarriage" if the party must incur expenses in connection with removal of the restraint or inhibition and the other party refuses to provide reasonable reimbursement for such expenses. "All steps solely within his or her power" shall not be construed to include application to a marriage tribunal or other similar organization or agency of a religious denomination which has authority to annul or dissolve a marriage under the rules of such denomination.

7. No final judgment of annulment or divorce shall be entered, notwithstanding the filing of the plaintiff's sworn statement prescribed by this section, if the clergyman or minister who has solemnized the marriage certifies, in a sworn statement, that he or she has solemnized the marriage and that, to his or her knowledge, the plaintiff has failed to take all steps solely within his or her power to remove all barriers to the defendant's remarriage following the annulment or divorce, provided that the said clergyman or minister is alive and available and competent to testify at the time when final judgment would be entered.

8. Any person who knowingly submits a false sworn statement under this section shall be guilty of making an apparently sworn false statement in the first degree....

9. Nothing in this section shall be construed to authorize any court to inquire into or determine any ecclesiastical or religious issue. The truth of any statement submitted pursuant to this section shall not be the subject of any judicial inquiry, except as provided in subdivision eight of this section.

123. Id. $\S 253(7)$.

124. Id. $\S 253(1)-(2)$. 
marry within Judaism to which the availability of civil divorce contributes.

\section{B. Endorsement}

Although the get statute benefits observant Jewish women at risk of being civilly divorced without receiving a get, it does not suggest impermissible endorsement of religion or of the Jewish religion. The statute is written in religiously neutral terms and extends to "conscientious restraints or inhibitions." ${ }^{\prime 25}$ It thus anticipates any situation where a party to a divorce may impede the remarriage of the other party. ${ }^{128}$ The scope of the statute, though, is limited to parties originally married in a religious ceremony. ${ }^{127}$ The statute does not promote a particular type of religious marriage or divorce, or religious marriage and divorce generally, but merely conditions civil dissolution of a marriage on satisfaction of requirements that were implicit at its inception.

The inquiry regarding the statute's potential for endorsement, however, may not stop with the statute's text. A person acquainted with the statute's history ${ }^{128}$ would be aware that it was passed specifically to alleviate a problem arising in the interaction between Jewish and civil law. ${ }^{128}$ Consequently, it is necessary to consider whether, as applied to parties married within Judaism, the statute does not impermissibly endorse that religion. Insofar as the get statute requires a party married in a Jewish ceremony to appear before a rabbinic tribunal in order to receive a civil divorce, the statute might appear to endorse the Jewish religion. However, certain aspects of Jewish law militate against this view.

In Judaism, the legal dimensions of marriage are essentially contractual. ${ }^{130}$ Marriage terminates either upon the death of one party or upon the presentation of a get. ${ }^{131}$ By appearing before a rabbinic tribunal the husband is fulfilling an obligation he incurred upon entering a Jewish marriage. ${ }^{\mathbf{1 3 2}}$ In requiring the "removal of barriers to remarriage" as de-

125. Id. $\S 253(6)$.

126. The statute, however, does not require parties married within Catholicism to seek an annulment in order to procure a civil divorce. See id. § 253(6).

127. N.Y. Dom. REL. LAW $\S 253(1)-(2)$ (McKinney 1986).

128. Familiarity with the statute's historical context is important in assessing the statute's potential for endorsement. See supra notes 94-95 and accompanying text.

129. See N.Y. DoM. REL. LAW § 253 practice commentary at 851-52 (McKinney 1986).

130. I. KLEIN, supra note 1 , at 382 .

131. I. HAUT, supra note 1, at 17. Marriage has both a religious and a legal aspect. The latter concerns the obligations that the partners in a marriage have assumed towards each other, which are enforceable in court. I. KLEIN, supra note 1 , at 382 .

132. In Orthodox Judaism, the marriage contract states that the parties are betrothed according to the laws of Moses and Israel; by this contract the husband assumes towards his wife the obligations prescribed by Jewish law. See M. LAMM, supra note 1, at 197-200. These include delivery of a get upon separation of the spouses. Deuteronomy 24:1. 
fined in the religious tradition within which the marriage was enacted, the statute enforces this obligation. Similarly, in the commercial context, courts enforce arbitration agreements to appear before rabbinical tribunals and abide by their decisions. ${ }^{133}$ The statute effectively remedies a religious bias that was masked in the formal neutrality of civil divorce prior to the get statute. The assumption that marriage is a status under the control of a court, rather than a contract between two parties, originates in a particular religious tradition. ${ }^{134}$

\section{Imposition of Religious Beliefs}

Courts might be prohibited from requiring the removal of barriers to remarriage if such removal required the affirmance of a religious belief. The delivery of a get, however, involves neither professions of faith nor devotional acts. ${ }^{138}$ The text of the get makes no reference to God by name. It merely states that the husband is releasing the wife from her marital obligations and freeing her to remarry. ${ }^{136}$ Like a Jewish commercial contract, the exchange of a get is exclusively regulated by the "civil" aspect of Jewish law, which governs relationships between human beings. ${ }^{137}$

If the husband was married in a Conservative ceremony, the marriage contract that he signed may in addition have provided that at the summons of one party the other party would appear in front of a rabbinical tribunal and comply with its decision. I. HAUT, supra note 1, at 64 .

In Avitzur v. Avitzur, 58 N.Y.2d 108, 446 N.E.2d 136, 459 N.Y.S.2d 572, cert denied, 464 U.S. 817 (1983), the New York Court of Appeals enforced the terms of a marriage contract requiring the parties to appear before a rabbinical tribunal in the event of marital difficulties. The court found that it could enforce the terms of the marriage contract by applying "neutral principles of contract law." 58 N.Y.2d at 114-15, 446 N.E.2d at 138-39, 459 N.Y.S.2d. at 574-75. "This approach contemplates the application of objective, well-established principles of secular law to the dispute, . . , thus permitting judicial involvement to the extent that it can be accomplished in purely secular terms." Id. at 115, 446 N.E.2d at 138, 459 N.Y.S.2d at 574 (citation omited). The Supreme Court has upheld the neutral principles of law approach under the establishment clause as a method of resolving church property disputes. Jones v. Wolf, 443 U.S. 595, 602 (1979); see also Minkin v. Minkin, 180 N.J. Super. 260, 434 A.2d 665 (Ch. Div. 1981) (requiring husband to obtain a get pursuant to marriage contract under which parties agreed to conform to laws of Moses and Israel).

133. See, e.g., Kingsbridge Center of Israel v. Turk, 98 A.D.2d 664, 469 N.Y.S.2d 732 (1983) (upholding rabbinical court resolution of dispute arising under employment contract stipulating that disputes would be decided by rabbinical court); see also Gelbfish v. Grossman, 46 A.D.2d 863, 361 N.Y.S.2d 673 (1974) (staying action arising from property dispute pending arbitration by rabbinical tribunal).

134. See H. Clark, Jr., Cases and Problems on Domestic Relations 7 (1980). Although the American colonies did not inherit English ecclesiastical courts, they received the English ecclesiastical rules regarding marriage. Id. These rules were administered by civil courts. See, e.g., G. HAsKins, LAW AND Aưthority in EARLy MASSAChuSETTS 63, 195 (1960). Under these rules a divorce was effected through a petition to a court. See 2 G. Howard, A History of Matrimonial InstiTUTIONS 366-67 (1904). For a discussion of the earlier progression from marriage and divorce at the husband's will to marriage and divorce under ecclesiastical courts, see generally 1 \& 2 G. HowARD, supra.

135. See I. HAUT, supra note 1, at 31-41 (describing get procedure).

136. Id. at 17-18.

137. See I. KLEIN, supra note 1, at 382. In Minkin, the court held that enforcement of a marriage contract requiring the procurement of a get did not violate the establishment clause because exchange 


\section{Nonentanglement}

The get statute's operation risks governmental entanglement with religion in two ways. First, the statute appears to require judges to decide the doctrinal question of whether the barriers to the remarriage of a party to divorce have been properly removed under Jewish law. ${ }^{138}$ Second, by allowing the cleric who solemnized the original marriage to contest by affidavit a party's claim that barriers to the other party's remarriage have been removed, the statute appears to give a religious functionary discretion over a governmental function, the granting of a divorce. ${ }^{139}$ The statute, however, can be read narrowly to avoid these apparent entanglements.

Whether a get has been exchanged is not a complex doctrinal question; it is a factual matter, readily ascertainable within the Orthodox or Conservative tradition. A certificate signed by the rabbis who supervised the get demonstrates compliance with the technical requirements for the presentation of a get. ${ }^{140}$ The only doctrinal question that may arise is whether a get exchanged in the Conservative tradition is sufficient to constitute a valid get in the Orthodox tradition. To avoid resolving this problem, courts should interpret the statute narrowly, according to its terms, which require the removal of barriers to remarriage as such barriers are defined by the tradition within which the original marriage took place. ${ }^{141}$ To decide this issue, the get statute requires that the court defer to the authority who is most competent to determine this fact: the cleric who solemnized the wedding. ${ }^{142}$

In property disputes between church factions, courts are permitted under the establishment clause to defer to the highest authority within a hierarchical church on the issue of which faction legitimately represents the church. ${ }^{143}$ In limiting the entry of an affidavit specifically to the cleric who originally solemnized the marriage, the statute functions like the rule providing for courts' deference to a religious authority in a property dispute. To avoid excessive entanglement with religion, courts may not permit anyone but the cleric who officiated at the original wedding to enter an affidavit regarding the removal of barriers to remarriage. ${ }^{144}$

of a get was "devoid of any religious connotation." Minkin v. Minkin, 180 N.J. Super. 260, 266, 434 A.2d 665, 668 (Ch. Div. 1981).

138. N.Y. DOM. REI. LAW § 253(3), (6) (McKinney 1986).

139. Id. \& 253(7).

140. See G. HoRowirz, supra note 5, at 281. For an example of a Conservative certificate of divorce, see I. KLEIN, supra note 1 , at 490.

141. N.Y. DOM. REL. LAW § 253(6) (McKinney 1986).

142. Under the statute an affidavit by the cleric who solemnized the original marriage takes priority over any affidavits entered by the parties. Id. $\S 253(5)$.

143. See Serbian Eastern Orthodox Diocese v. Milivojevich, 426 U.S. 696, 724-725 (1976).

144. The statute specifically avoids providing for an alternative if the original cleric has passed 
The get statute removes governmentally imposed burdens on religious exercise and, consequently, promotes free exercise norms. Because it neither endorses nor requires the affirmance of religious beliefs, and it can be interpreted narrowly to avoid excessive government entanglement with religion, it should be upheld as a permissible accommodation of religion.

\section{E. Potential Free Exercise Challenges}

A husband originally married under Jewish law but subsequently converted to a different religion may claim that complying with the get statute violates his free exercise of religion. If the dictates of his religion conflict with the giving of a get then the statute directly burdens his religious exercise. In such circumstances his claim should be treated no differently from any other claim for an exemption under the free exercise clause. ${ }^{145}$

\section{Conclusion}

A systematic resolution of the constitutional questions raised by the get statute will require the courts to apply the nonestablishment mandate to accommodations of religion. This Note proposes a standard to determine the permissibility of accommodations of religion to assist courts confronted with the constitutionality of legislation intended to remove burdens on religious exercise created by government action. Application of the standard to the get statute suggests its validity under the establishment clause.

The usefulness of the proposed approach extends beyond its application to the get statute. An analysis that focuses first on whether legislation removes governmentally imposed burdens on religious exercise should provide the basis for a unified approach to a broad range of establishment problems that might otherwise appear so diverse as to preclude common analysis. At base, the approach reflects the concern for religious liberty that is the core of the religion clauses.

away. N.Y. DOM. REL. LAw $\S 253(7)$. This limitation may make the statute underinclusive; but it is preferable to encouraging courts to become entangled impermissibly with religion.

145. See supra notes $37-43$ and accompanying text. 
